\title{
A Review of Current Research on Natural Skin Whitening Products
}

\author{
Sun-Hee Jeong \\ Department of Beauty \& Art, Suwon Women's University, Suwon-si, Gyenggi-do, Korea
}

Corresponding author: Sun-Hee Jeong, Department of Beauty \& Art, Suwon Women's University, 72 Onjeong-ro, Gwonseon-gu, Suwon-si, Gyeonggi-do 16632, Korea

Tel.: +82 312908375

Fax: +82 312908030

Email: sunheejeong@swc.ac.kr

Received July 23, 2018

Revised October 3, 2018

Accepted October 18, 2018

Published December 30, 2018

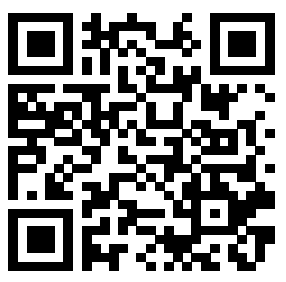

\begin{abstract}
In the Eastern world, having white skin is considered a key factor for looking beautiful, resulting in many consumers desiring to have white skin and continuous growth in the whitening cosmeceuticals market. Hundreds of companies, including AmorePacific and LG Household \& Health Care, have developed and released products in this market, increasing their range in a systematic and strategic manner through market survey and analysis. In the cosmetics industry, it is important to develop high-performance chemicals that are suited to the properties of the skin. However, safety is even more critical because these products will be applied to the human body, and side effects of whitening agents and drugs have recently been reported. Therefore, there is a need for continued research not only to improve these properties but also to enhance mid- and long-term growth in the market. The aim of this study was to review current research on natural skin whitening products and to examine their ingredients, with a particular focus on Prunus persica Flos, Phellodendron amurense, Cudrania tricuspidata Bureau, Zanthoxylum schnifolium, Dendropanax morbifera, and Broussonetia kazinoki. Prunus persica Flos, Phellodendron amurense and Dendropanax morbifera have shown the high inhibition rate of melanin biosynthesis, and Cudrania tricuspidata Bureau and Zanthoxylum schnifolium have shown the inhibition of oxidization by inhibiting tyrosinase. Broussonetia kazinoki have shown the effect of anti-oxidant by eliminating reactive oxygen species (ROS).
\end{abstract}

Keywords: Cosmeceuticals market, Safety, Whitening agent, Natural, Ingredient

\section{Introduction}

최근 아시아 기능성 화장품 산업에서 활발하게 연구되고 있 는 분야 중에 하나는 미백 효능이라 할 수 있다. 동양에서는 예로 부터 흰 피부가 미인을 가늠하는 하나의 기준으로 자리 잡아 피 부 미백 선호 소비자층이 두터우며, 이로 인해 미백 화장품시장 은 지속적인 성장세를 유지하고 있다. 미백기능을 강조한 기능성 화장품 시장에서 아모레퍼시픽, $\mathrm{LG}$ 생활건강 등 수백 개의 기업 들이 앞 다투어 제품을 개발하고 있고, 국내외 시장 조사와 분석 을 통하여 체계적이고 전략적인 시장규모를 키우고 있다(Park \& Kim, 2017).

Melanin의 색소침착은 인체의 병리적인 문제와 함께, 미용 적인 측면에서도 문제로 인식되고 있다. 자외선으로 인한 활
성산소에 의해 세포가 손상을 입어 피부면역 기능이 저하되 고, 탄성 섬유가 변성되는 등 각종 피부장애를 일으킬 수 있 다. 미백과 관련된 연구는 tyrosinase 활성 억제 및 저해, dihydroxyphenylalanine (DOPA) 산화 억제, 각질층 박리 촉진 및 자외선 차단 등이 있다. 각질형성세포에 있는 melanin의 양 과 분포에 의해 피부색 그리고 피부색소 침착을 결정하므로, 미 백효과를 위해서는 melanin 형성 억제, 즉 tyrosinase 활성 억 제가 매우 중요하다고 볼 수 있다(Cho, 2011). Tyrosinase의 주요 길항물질로는 arbutin, kojic acid, linoleic acid, azelaic acid가 있지만, 많은 부작용 사례가 나오고 있다(Han \& Park, 2006).

미백 화장품은 피부특성에 맞는 우수한 화학 소재 개발도 중요 하지만, 인체에 적용되어 사용되는 만큼 안전성 측면이 매우 강 
조되고 있다. 최근에는 화학성분의 미백제와 약물에 대한 부작용 으로 인체에 대한 부작용이 대두됨에 따라, 부작용이 대체로 적 은 천연물질을 이용한 melanin 생성 억제 및 활성 산소소거기 능을 가진 미백소재 연구가 활발히 진행 하고 있다(Han \& Yi, 2012; Kim \& Lee, 2014; Yoon et al., 2013). 자연성, 식물 성, 천연성을 선호하는 소비자의 심리가 크게 작용하여 이를 제 품에 적극적으로 반영한 여러 다양한 천연 화장품이 각광받고 있 다(Kim \& Han, 2013; Xiaoquian \& Lee, 2018).

미백 화장품에 대한 천연 소재에 대한 탐색은 전 세계적으로 많이 시도되었고, 많은 연구성과를 가져왔다. 이를 바탕으로 천 연 화장품의 인기는 아시아 지역에서 높게 성장하고 있으며, 중 국 천연 화장품 규모는 2011년 70억 달러에서 2013년 121억달 러로 성장하였다. 식품의약품안전처에 의하면, 2014 년 기준으 로 국내 천연 화장품 시장은 약 900 억원의 규모를 나타내고 있 으며, 연평균 8-9\%씩 성장하고 있다(Park \& Kim, 2017). 따 라서 본 연구는 화장품의 원료로 미백기능이 입증되거나 기대 효 과를 보이는 다양한 자연 유래들에 대한 연구와 실험 방법에 대 해 조사해보고, 기능성 화장품으로서의 응용가능성을 확인해 보 고자 한다.

\section{1. 미백 화장품의 특성}

기능성 화장품이란 화장품이 통상 갖는 세정이나 보습의 미용 효과 이외에 별도의 기능을 갖는 화장품을 의미한다. 화장품 법 에 의하면, 기능성 화장품은 피부미백에 도움을 주는 제품, 피 부주름 개선에 도움을 주는 제품, 피부를 곱게 태워주는 제품, 자외선으로부터 피부를 보호하는 데에 도움을 주는 제품, 그리 고 항염증, 탈모 방지, 비만 개선 등과 같이 의약품과 유사한 치 료활성에 해당하는 기능을 가진 제품이라 정의하고 있다. 기능 성 화장품 중 하나인 미백 화장품은 피부에 침착된 melanin의 색을 엷게 하여 피부의 미백에 도움을 준다. 자외선 차단제가 melanin을 만드는 자외선을 차단한다면, 미백 화장품은 자외선 을 받은 뒤 melanin이 만들어지지 않게 하는 기능을 한다(Ha, 2016).

미백의 유효성분은 크게 melanin pigment의 생산을 돕는 tyrosinase에 직접 작용하여 활성억제 실험이 주를 이루고 있 었으나, 최근 들어 tyrosinase 유전자 발현억제, tyrosinase 생 성억제, tyrosinase 분해촉진, tyrosinase glycosylation 저 해 등 다각적인 실험 및 연구로 미백 효과를 입증하려 노력하고 있다(Costin \& Hearing, 2007; Hearing \& Jiménez, 1987; Mason, 1948; Schallreuter et al., 1998). 식약처에서 안정성 과 안전성이 확보되고 여러 많은 연구결과를 통해 미백효과가 입 증된 원료에 대해 기능성 미백원료로 고시하고 있다.

식약처에서 미백성분으로 등록된 물질은 총 8 가지로, Broussonetia Kazinoki root extract, arbutin, ethyl ascorbyl ether, Glycyrrhiza glabra root extract, ascorbyl glucoside, magnesium ascorbyl phosphate, niacinamide, alphabisabolol, ascorbyl tetraisopalmitate이다. 식약처는 미백물질 농도가 일정 기준 이상 되어야 기능성 화장품으로 인정하고 있 다. 미백 물질은 일정량 이상이 되어야만 실제로 효능을 발휘하 기 때문이다. 자세한 기준 함량은 아래 Table 1과 같다(Kim et al., 2017).

Melanin은 아미노산의 일종인 tyrosine이 산화과정을 거치 며 합성되는 고분자 색소이다. Melanin은 피부 아래층에 위치한 melanocyte에서 생성되며, tyrosine이 tyrosinase라는 산화효 소 작용으로 $\mathrm{DOPA}$ 물질로 변화하고 $\mathrm{DOPA}$ oxidase 효소 작용 으로 DOPA quinine으로 변화하여 melanin이 만들어진다. 미 백 화장품은 의약부외품의 효능 범위가 약사법에 의해 인정되고 있다. 미백을 목적으로 한 성분을 배합한 화장품을 미백 화장품 이라고 하며 단계별, 라인별 시스템화 하면서 고가의 프리미엄 급 브랜드 시장을 형성해 나가고 있는 추세로 피부의 각질 및 노 폐물을 제거해 피부 투명도를 높여주는 클렌징 라인에서부터 시 작해 집중적인 피부톤 개선 시스템에 이어 집중관리를 위한 특수 케어까지 단계별 시스템으로 이루어지고 있다(Kim, 2006).

\section{2. 천연 화장품의 특성}

천연 화장품은 보통 과일이나 꽃 그리고, 약재 성분에서 추출 한 원료로 제조된 화장품을 말한다. 최근 천연 화장품에 대한 중 요성과 수요 증대가 전 세계적 트랜드로, 점차 시장이 확대되고

Table 1. Standard concentration of whitening ingredients

\begin{tabular}{clr}
\hline & Whitening ingredients & Standard concentration \\
2 & Broussonetia kazinoki root extract & $2 \%$ \\
3 & Arbutin & $2-5 \%$ \\
4 & Ethyl ascorbyl ether & $1-2 \%$ \\
5 & Glycyrrhiza glabra root extract & $2 \%$ \\
6 & Ascorbyl glucoside & $3 \%$ \\
7 & Magnesium ascorbyl phosphate & $2-5 \%$ \\
8 & Alphacinamide & $0.05 \%$ \\
9 & Ascorbyl tetraisopalmitate & $2 \%$ \\
\end{tabular}


있다. 화장품 개발에 있어 안전성이 매우 중요한데, 유럽, 미국 등의 나라에서 광우병 발병으로 동물 유래의 화장품 소재들이 대 부분 식물 유래의 소재로 급격히 대체되었고, 이에 따라 식물 유 래의 천연 화장품 원료개발이 박차를 가하게 되었다(Jin et al., 2004; Kim, 2006). 특히 화장품 강국으로 꼽히고 있는 프랑스, 미국, 일본 등 글로벌 화장품 기업들이 세계 시장에서 천연 화장 품의 점유율을 적극적으로 확대하고 있다.

또 다른 천연 화장품시장 확대의 주된 이유로는 피부질환 환자 의 급증 및 대기 오염에 대한 우려로, 피부에 자극이 없는 천연원 료를 사용한 천연 화장품에 대한 수요가 지속적으로 증가되고 있 다. 천연물을 사용하는 이유는 민간처방에 의해 오랫동안 약재 로 사용되어 인체에 대한 효능 및 부작용이 검증되어 있고, 다양 한 효능을 갖는 성분들이 풍부하게 존재하고 있기 때문이다(Kim et al., 2004). 일본에서는 예부터 미강이나 수세물 등을 이용하 여 피부를 가꿔왔고, 중국에서는 약초를 화장품으로 이용하였다. 화장품에 이용되는 천연물은 생체에 대해 약리학적으로 유효성을 나타내는 생약이 많으며, 그 실체는 여러 가지 화학물질의 혼합물 이라 할 수 있다. 천연 화장품 원료는 스킨, 로션 등 제품마다 차 이가 있지만, 대게 20-30가지의 원료가 들어가게 된다.

천연 화장품에 대한 중요성은 세게 공통으로 커지고 있으나, 이 에 대한 규정 및 인증 취득 절차는 국가별 지역별로 상이하다. 국 가별로 천연 화장품에 대한 개별적 규정 및 범위를 정하여 엄격한 요건을 충족하도록 요구하고 있는 것이다(Kim et al., 2017). 그 에 반해, 현재 한국에서는 천연임을 인증하는 제도가 없어 소비자 들이 화장품의 정보를 쉽고 정확하게 확인하긴 어렵다.

\section{3. 천연 미백원료의 연구 동향}

최근 화장품에 대한 안전성 측면이 주목됨에 따라, 천연 물질 을 이용한 melanin 생성 억제 및 활성 산소 소거능을 가진 미백 소재 연구가 활발히 진행되고 있다. 자연 유래 천연 미백 원료들 의 연구는 아래와 같으며, 관련된 원료의 학명과 주요 성분들은 Table 2 와 같다.

\section{1) 도화}

도화(Prunus persica Flos)는 복사꽃이라 하고 복숭아나무를 복사나무라고도 부른다. 고려도경이라는 한방서적에서는 "성질
이 고르고 맛이 쓰며 독이 없고, 석림을 깨트리고, 대소변을 이롭 게 하며 세 가지 벌레를 내리고 주와 악귀를 죽이고 얼굴빛을 아 름답게 한다"하여 대장에 발생하는 병이나 얼굴에 나타나는 부스 럼 등에 사용했다는 기록이 있다(Heo, 1994; Son et al., 2012; Seo \& Lee, 2000). 또한 건포, 습진에 복숭아 잎과 함께 달여 목 욕물에 넣기도 하고 외용하기도 했다(Park et al., 2005). 도화 는 노화와 알츠하이머에 관여하는 cholinesterase를 저해하는 활 성, cisplatin에 의한 간독성의 부작용 완화가 대표적인 효과이다 (Bae \& Kim, 2003). 도화에는 lipid transfer protein으로 구성 된 allergen 등의 allergy 유발 물질을 함유하고 있는 반면, 과실 의 $70 \%$ 에탄올 추출물이 $\mathrm{HMC}-1$ 세포의 염증반응에서 $\mathrm{NF}-\mathrm{kB}$, $\mathrm{IL}-6$, tumor necrosis factor $\alpha$ (TNF $\alpha)$, histamine 생성 등을 억제하는 항염증 효과를 보이는 것으로 보고되었다(Suh et al., 2006; Yoo et al., 2005).

손형우 등의 연구에서는 꽃(도화)과 꽃받침(도화악)의 증류수 및 에탄올 추출물로부터 미백 활성을 측정하였다. Tyrosinase에 의한 미백활성을 비교한 결과, $10 \mathrm{mg} / \mathrm{mL}$ 농도를 기준으로 복숭 아꽃 증류수 추출물 $40 \%$, 에탄올 추출물 $32 \%$, 복숭아꽃받침 증 류수 추출물 $53 \%$, 에탄올 추출물 $43 \%$ 의 저해율로 복숭아 꽃받 침 증류수 추출물에서 가장 높은 활성을 나타내었다. $\mathrm{B} 16 \mathrm{~F} 10$ 세 포에서 melanin 생합성 억제를 측정한 결과, 복숭아 꽃 에탄올 추 출물은 $10 \mu \mathrm{g} / \mathrm{mL}$ 에서 $57 \%, 100 \mu \mathrm{g} / \mathrm{mL}$ 에서 $76 \%$ 의 억제효과 를 나타냈다. 그리고 복숭아 꽃받침 에탄올 추출물은 $10 \mu \mathrm{g} / \mathrm{mL}$ 에서 $63 \%$ 의 억제 효과를 확인하였다(Son et al., 2012). 이진영, 안봉전의 연구에서도 피부 내에서 melanin 중합체 생합성을 효과 적으로 저해할 수 있는 tyrosinase 저해 활성을 측정한 결과, 도 화 추출물의 활성이 우수함을 확인할 수 있었다. 또한, 도화 추출 물의 melanoma 세포에서의 tyrosinase 저해 활성이 우수함을 확 인하였다. 그리고, 도화 추출물을 천연 미백제로 사용하기 위하여 melanoma 세포에서의 melanin 생합성을 측정한 결과, 도화추출 물의 melanin 저해 효과가 우수함을 확인할 수 있었다. 또한 섬유 아세포를 이용한 collagen 생합성량을 측정한 결과, 도화 아세톤 추출물 $100 \mathrm{ppm}$ 에서 $41.0 \%$ 의 촉진 효과를 나타내어 도화 아세톤 추출물의 주름 개선 효과가 우수함을 확인하였다. 이상의 결과로 부터 도화 추출물의 미백 효과가 있음을 확인할 수 있었다(Lee \& An, 2010).

Table 2. Botanical names and major chemical constituents of natural whitening materials

\begin{tabular}{lll}
\hline Botanical name & & \\
Peach blossom & Prunus persica Flos & Chemical composition \\
Phellodendron bark & Phellodendron amurense & Berberine, Palmatine, Alkaloids, Limonin, Obacunone \\
Mulberry & Cudrania tricuspidata Bureau & Polyphenol, Flavonoids, Coumarin, Stilbenes \\
Chinese pepper & Zanthoxylum schnifolium & Limonene, Citronellal, Phellandrene, Sanshool, Flavonoid \\
Korean dendropanax & Dendropanax morbifera & B-selinene, Capnellane-8-one \\
Paper mulberry & Broussonetia kazinoki & Kazinol J, Luteolin \\
\hline
\end{tabular}




\section{2) 황백}

황백(Phellodendron amurense)은 운황과(Rutaceae) 식물에 속하는 황백나무의 껍질을 말려 약용으로 사용하는 것으로, 우 리나라 전역에서 자생되고 있다(An, 1998), 황백 추출물을 천연 미백제로 사용하기 위하여 melanoma 세포에서의 melanin 생 합성을 측정한 결과, melanin 생성 억제 효과가 있음을 알 수 있 었고, 황백 추출물에서 미백 물질을 분리하여 tyrosinase 억제 효과를 검토한 결과 긍정적인 효과가 확인되었다. 황백 추출물을 천연 미백제로 사용하기 위하여 melanoma 세포에서의 melanin 생합성을 측정한 결과, melanin 생성 억제 효과가 있음을 확인 할 수 있었다. 또한, 피부 내에서의 melanin 중합체 생합성을 효 과적으로 저해할 수 있는 정제물의 tyrosinase 저해활성을 측정 한 결과, 천연자원으로서의 황백은 미백 활성이 우수함을 확인할 수 있었다(Cho, 2011; Lee et al., 2007).

\section{3) 구찌뽕나무}

구찌뽕나무(Cudrania tricuspidata Bureau)는 뽕나무과에 딸 린 낙엽소교목 또는 관목으로서 전남북, 경남북, 충남지방과 중 국, 일본 등 지네서 자생하는 식물이다. 구찌뽕나무, 활뽕나무 등의 다른 이름이 있고, 중국에서는 자목 또는 상자, 지황 등으 로 부른다. 약으로 사용 시에는, 줄기, 줄기껍질, 열매, 잎, 뿌리 를 사용하며, 약성은 따뜻하다. 여성들의 여러 가지 질병에 좋다 고 알려져 있으며, 근골을 튼튼하게 하고 혈액을 맑게 하는 작용 이 있다(Choi et al., 2015). 신혜진 등의 연구에서는 구찌뽕나 무 뿌리 추출물은 $500 \mu \mathrm{g} / \mathrm{mL}$ 농도에서 $81 \%$ 의 tyrosinase 억제 효과와 58\%의 elastase 억제 효과가 있었고, UVB에 대해서도 다소의 흡수력을 보여주었다. 또한, $500 \mu \mathrm{g} / \mathrm{mL}$ 농도 DOPA 산 화억제 효과실험에서 DOPA의 $82 \%$ 의 우수한 억제율을 보이며, 대조군인 albutin에 비해 미백효과가 전반적으로 우수함을 나타 내었다(Shin et al., 2014).

\section{4) 산초}

산초(Zanthoxylum schnifolium)는 운향과(Rutaceae)의 초 피나무 또는 동속 식물의 과피로서 씨를 제거하여 만든 약재이 다. 아시아 서부에서 주로 서식하는 자생식물로 한국, 일본, 중 국 등에서 식품의 향신료로 사용되고 있다. 특유의 향이 있으 며 맛은 맵고 성질은 따뜻하여 예로부터 감기, 복통 설사, 치 통, 천식 등에 쓰여 왔으며 살충작용, 항균작용, 소화불량 등 에 효과가 있는 것으로 알려져 있다. 이전 연구에서 산초 열매 의 항암활성, 항진균 활성, 산초 종유의 항균활성, 산초 뿌리, 줄기 및 잎 추출물의 항산화 및 항혈전 효과 등이 밝혀진바 있 다(Han et al., 2011). 진경숙 등의 연구에서는 한방에서 약재 로 사용되는 산초 과피 추출물의 항산화, 미백 및 항염증 활성 을 in vitro assay system 및 cell culture model system을 이
용하여 분석함으로써 기능성 소재로서의 활용가능성을 확인하 였고, $\mathrm{MeOH}, \mathrm{EtOH}$, 열수 추출물 모두 강한 $\mathrm{DPPH}$ radical 소 거 활성 및 tyrosinase 효소 활성 저해를 통한 DOPA 산화 억 제능을 보였다. B16F10 mouse melanoma cell을 이용하여 $\alpha$-melanocyte-stimulating hormone ( $\alpha$-MSH)에 의해 유도 된 세포 내 melanin 생성에 미치는 산초 추출물의 영향을 알아 본 결과, 농도의존적인 melanin 생성 억제능을 보였고 세포의 tyrosinase 활성 저해능 또한 이와 일치하는 결과를 보여 산초 추출물에 의한 melanin 생성 억제능이 tyrosinase 효소 활성 억 제 및 melanogenesis 관련 단백질 발현을 저해하여 미백 화장품 으로서의 활용성을 보여주었다(Jin et al., 2012).

\section{5) 황칠나무}

황칠나무(Dendropanax morbifera)는 우리나라의 남부 해안 지역과 제주도 등에서 자생하는 쌍떡잎 식물이며 두릅나무과의 상록 교목으로, 뿌리와 잎의 줄기는 거품습, 황멸맥, 풍습 비통, 편두통, 월경불순에 효능이 있다고 알려져 왔다(Jeong et al., 1995). 또 황칠나무에는 sesquiterpene에 속하는 $\beta$-selinene 이 가장 많이 함유되어 있고, capnellane-8-one가 다음으로 많 이 함유되어 있다고 알려져 있다(Kim \& Chung, 2000). 박수아 등의 연구에서는 황칠나무 잎 추출물의 $\mathrm{HaCaT}$ 세포에서의 항산 화 활성과 $\mathrm{B} 16 \mathrm{~F} 1$ melanoma 세포에서의 미백 활성을 측정하였 다. UVB $800 \mathrm{~mJ} / \mathrm{cm}^{2}$ 를 $\mathrm{HaCaT}$ 세포에 조사하였을 때, 황칠나 무 잎 추출물은 농도 의존적이고 자외선으로부터 세포를 보호하 였다. 황칠나무 잎 추출물의 B16F1 melanoma 세포에서의 미백 활성을 측정한 결과, 미백제로 알려진 albutin 보다 더 우수한 melanin 합성 저해 활성을 보였다. 이상의 결과들을 황칠나무 잎 추출물이 ROS에 대항하여 세포를 보호함으로써 생체계, 특히 태양 자외선에 노출된 피부에서 세포 보호제 및 천연 항산화제로 서 작용할 수 있음을 가리키며, $\alpha-\mathrm{MSH}$ 로 유도된 melanin 생합 성 저해 효과로부터 황칠나무 잎 추출물이 새로운 미백 화장품의 원료로써 활용성을 보여주었다(Park et al., 2013).

\section{6) 닥나무}

닥나무(Broussonetia kazinoki)는 한국, 대만과 일본에 널리 자생하고 있는 낙엽활엽관목으로 주로 낮은 산지에서 자생한다. 동의보감에 닥나무의 과실은 저실자라 하여 요통이나 부종치료 에 효능이 있고, 닥나무껍질은 저수피라 하여 수종과 창만을 주 치하며 물을 몰아내며 소변을 잘 보게 한다고 기재되어 있다. 닥 나무는 약재로 쓰이는 것보다 주로 전통한지를 만드는 주재료로 알려져 있으며, 최근 닥나무 추출물이 미백 효과가 있는 것으로 보고 되고 있다(Zhang et al., 2001). 박수아 등의 연구에 의하 면, 적혈구의 광용혈 실험에서 대표적인 항산화 물질로 알려진 $\alpha$-tocopherol 보다 세포보호 효과가 있으며, ROS를 소강시키 
거나 소거함으로써 세포막을 보호하고, 생체계 특히 태양 자외선 에 노출된 피부에서 항산화제로 작용할 수 있음을 확인하여 미백 화장품으로써의 활용성을 검증하였다(Park et al., 2013).

\section{Conclusion}

동양권에서의 뷰티시장 성장과 함께 자연주의 열풍으로 천연 소재 미백 화장품 원료의 연구는 활발히 진행되고 있다. 기능성 화장품의 법적인 체제 속에 비약적인 발전을 거듭하고 있는 미백 시장은 천연성분에 기반을 둔 신 원료 개발의 열기로 착실한 성 장을 거듭할 것으로 예상되고 있다. 초기에는 tyrosinase 활성 억제제와 melanin 배출 촉진을 위한 각질 제거제의 복합 사용이 주를 이루던 미백시장이 피부과학 분야의 괄목할 만한 연구 성과 에 힘입어 다원화한 미백 효과와 상호보완적인 복합 처방으로 미 백기능을 더욱 높이고 있다. 미백제의 연구는 melanin 생합성 경로에 작용하는 기작을 중심으로 해서 이루어지고 있으며, 도 화, 황백, 구찌뽕나무, 산초 등 천연유래 물질들이 특정 단계 또 는 여러 단계에서 색소 생성을 방해함으로써 미백효과를 나타낼 수 있음을 보았다.

이와 같이 천연물을 원료로 한 미백 가능성 소재로 많이 개발 되었으나, 열처리 및 기계적 파쇄로 인한 영양 및 생리활성 성분 들의 파괴, 색이나 향기와 같은 기호성분의 변화, 부유물질의 생 성 등은 아직까지 해결해야 할 숙제로 남아 있다. 이러한 숙제들 을 중장기적으로 연구하여 해결한다면, 고부가치산업으로서 기 술 축적과 안정적인 고객 확보에 힘입어 미백 시장을 선도해 화 장품 산업 활성화에 기여할 수 있을 것이다.

\section{References}

An DG. Illustrated book of Korean medicinal herbs. Kyohak Publishing, Seoul, pp1-98, 1998.

Bae YK, Kim JD. Study on Korean women's knowledge and usage behaviors of cosmeceuticals. Journal of the Society of Cosmetic Scientists of Korea, 29: 251-270, 2003.

Cho YJ. Characteristics of cosmetic with whitening compounds from Phellodendron amurense. Journal of Applied Biological Chemistry, 54: 108-113, 2011.

Choi SW, Lee YJ, Ha SB, Jeon YH, Lee DH. Evaluation of biological activity and analysis of functional constituents from different parts of mulberry (Morus alba L.) tree. Journal of the Korean Society of Food Science and
Nutrition, 44: 823-831, 2015.

Costin GE, Hearing VJ. Human skin pigmentation: melanocyte modulate skin color in response to stress. FASEB Journal, 21: 976-994, 2007.

Ha BJ. Cosmeceuticals. Shinkwang Publishing, Seoul, pp5666, 2016.

Han DH, Park KS. Analysis on the purchasing condition and satisfaction of whitening cosmetics. Journal of the Korean Society of Fashion \& Beauty, 4: 42-55, 2006.

Han JS, Yi DH. Effects of pine needles fermentation extracts on antioxidant activity and inhibition of melanin synthesis. Asian Journal of Beauty and Cosmetology, 10: 619-624, 2012.

Han W, Hu WC, Lee YM. Anti-cancer activity of human colon cancer (HT-29) cell line from different fraction of Zanthoxylum schnifolium fruits. Korean Journal of Pharmacognosy, 42: 282-287, 2011.

Hearing VJ, Jiménez M. Mammalian tyrosinase: the critical regulatory control point in melanocyte pigmentation. International Journal of Biochemistry, 19: 1141-1147, 1987.

Heo J. Donguilbogam. Daejoongseokwan Press, Seoul, pp173-1386, 1994.

Jeong BS, Jo JS, Pyo BS, Hwang B. Studies on the distribution of Dendropanax morbifera and component analysis of the golden lacquer. Korean Society for Biotechnology and Bioengineering Journal, 10: 393-400, 1995.

Jin KS, Oh YN, Park JA, Lee JY, Jin SJ, Hyun SK, Hwang HJ, Kwon HJ, Kim BW. Anti-oxidant, anti-melanogenic, and anti-inflammatory activities of Zanthoxylum schinifolium extract and its solvent fractions. Korean Journal of Applied Microbiology and Biotechnology, 40: 371-379, 2012.

Jin YZ, An SY, Hong ES, Lee GH, Kim EK, Row KH. Extraction of whitening agents from natural plants and whitening effect. Applied Chemistry for Engineering, 16: 348-353, 2004.

Kim HR, Chung HJ. Chemical characteristics of the leaves and the seeds of Korean Dendropanax (Dendropanax morbifera Lev.). Journal of the Korean Society of Applied Biological Chemistry, 43: 63-66, 2000.

Kim KY, Lee NK. Herbal extracts research trend that have effects on melanin production and control. Asian Journal of Beauty and Cosmetology, 12: 453-461, 2014. 
Kim KH, Ko KI, Kang EJ, Yang KE, Park SN. A research trend of natural product on well-being industry. Journal of the Society of Cosmetic Scientists of Korea, 30: 329-343, 2004.

Kim MS, Han JS. A study of effect of natural extract on improvement of hair damage. Journal of the Korean Society of Beauty and Art, 14: 249-262, 2013.

Kim KY, Bae YK, Lee EJ, Kim SM, Kim EY, Choi SK. Cosmetology. Medicean Publishing, Paju, pp161-194, 2017.

Kim EH. A study of whitening cosmetics from natural products. Asian Journal of Beauty and Cosmetology, 4: 195-203, 2006.

Lee JG, Choi JY, Oh JS, Jung HW, Choi EH, Lee HS, Kim JA, Chang TS, Son JK, Lee SH. Isolation of melanin biosynthesis inhibitory compounds from the Phellodendri Cortex. Korean Journal of Pharmacognosy, 38: 387-393, 2007.

Lee JY, An BJ. Whitening and anti-wrinkle effects of Prunus persica Flos. Microbiology and Biotechnology Letters, 40: 364-370, 2010.

Mason HS. The chemistry of melanin; mechanism of the oxidation of dihydroxyphenylalanine by tyrosinase. Journal of Biological Chemistry, 172: 83-99, 1948.

Park SA, Ha JH, Park SN. Antioxidative activity and component analysis of Broussonetia kazinoki SIEB extracts. Applied Chemistry for Engineering, 24: 177-183, 2013.

Park JS, Kim HG. The research of the way to gain domestic and foreign market economy force of whitening cosmetics. International Area Studies Review, 21: 121141, 2017.

Park SU, Park J, Park CI, Jie YJ, Hwang YC, Kim YH, Jeon $\mathrm{SH}$, Lee HM, Ha JH, Kim KJ, et al. Cellular antioxidant activity and whitening effects of Dendropanax morbifera leaf extracts. Microbiology and Biotechnology Letters, 41: 407-415, 2013.

Park YJ, Park YS, Jang HG, Kim TC, Hae BG. Utilization of pruning branch of peach tree as a natural dyeing material. Korean Journal of Plant Resources, 18: 71-77, 2005.

Schallreuter K, Slominski A, Pawelek JM, Jimbow K, Gilchrest BA. What controls melanogenesis? Experimental Dermatology, 7: 143-150, 1998.

Seo $\mathrm{MH}$, Lee YM. Easy to find our tree 1 mountain tree: spring. Hyeonamsa Press, Seoul, pp146-147, 2000.

Suh SJ, Koo BS, Jin UH, Hwang MJ, Lee IS, Kim CH. Pharmacological characterization of orally active cholinesterase inhibitory activity of Prunus persica L. Batsch in rats. Journal of Molecular Neuroscience, 29: 101-107, 2006.

Son HU, Lee SH, Kim MA, Park HJ, Lee SH. Comparison of melanogenesis-inhibiting activity by extracts of Prunus persica flower and calyx. Korean Journal of Food Preservation, 19: 946-950, 2012.

Shin HJ, Jeong HL, Hwang DB, Kim DU. Cudrania tricuspidata root extract as whitening and antiwrinkle cosmetic agent. Korean Chemical Engineering Research, 52: 701-705, 2014.

Xiaoquian T, Lee JH. Evaluation of moisture and satisfaction of lip balm using natural colors (cohineal, lac color, red radish color). Journal of the Korean Society of Beauty and Art, 19: 227-244, 2018.

Yoo ID, Kim JP, Kim WG, Yun BS, Ryoo IJ. Development of new natural antioxidants for cosmeceuticals. Journal of the Society of Cosmetic Scientists of Korea, 31: 349357, 2005.

Yoon MY, Han EH, Han YS. A study on anti-oxidant activity and whitening action of Plantago asiatica L. seed extract. Journal of the Korean Society of Beauty and Art, 14: 259-269, 2013.

Zhang PC, Wang S, Wu Y, Chen RY, Yu DQ. Five new diprenylated flavonols from the leaves of Broussonetia kazinoki. Journal of Natural Product, 64: 1206-1209, 2001. 


\section{국문초록}

\section{천연 미백원료의 최신 동향}

정선희

수원여자대학교 미용예술과, 경기도 수원시, 한국

본 연구는 천연 미백성분과 관련된 최신 연구 동향을 알아보는 데 그 목적이 있다. 동양에서는 예로부터 흰 피부가 미인을 가늠하는 하나의 기준으로 자리 잡아, 피부미백 선호 소비자층이 두터우며 미백 화장품시장은 지속적인 성장세를 유지하고 있다. 미백기능 을 강조한 기능성 화장품 시장은 아모레퍼시픽, 엘지생활 건강 등 수백 개의 기업들이 앞 다투어 제품을 개발하고 국내외 시장 조사 와 분석을 통하여 체계적이고 전략적인 시장규모를 키우고 있다. 화장품은 피부특성에 맞는 우수한 화학 소재 개발도 중요하지만, 인체에 적용되어 사용되는 만큼 안전성 측면이 매우 강조되고 있다. 최근에는 화학성분의 미백제와 약물에 대한 부작용으로 인체에 대한 위험성이 대두됨에 따라, 안전하면서도 미백 기능이 탁월한 천연 소재 미백 화장품 원료에 대한 최신 연구 동향을 탐색하였다. 본 논문에서는 천연 미백 화장품 성분으로 활용 가능성이 있는 도화, 황백, 구찌뽕나무, 산초, 황칠나무, 닥나무의 성분들을 검토하 였다. 도화와 황백 그리고 황칠나무 추출물에서는 melanin 생합성 억제율이 높았으며, 구찌뽕나무와 산초에서는 tyrosinase 활성저 해를 통한 dihydroxyphenylalanine 산화 억제능을 보였다. 그리고, 닥나무는 reactive oxygen species (ROS) 소거함으로써, 자외선 에 노출된 피부에 항산화제로 작용하며 미백기능을 보여주었다.

핵심어: 화장품시장, 안전성, 미백제, 천연, 성분

\section{참고문헌}

김경연, 이나경. 멜라닌 생성과 제어에 영향을 미치는 한방추출물 연구 동향. 아시안뷰티화장품학술지, $12: 453-461$, 2014.

김기호, 고강일, 강은정, 양은경, 박수남. 웰빙산업에서의 천연물 연구 동향. 대한화장품학회지, 30: 329-343, 2004. 김민선, 한진섭. 천연 추출물의 손상모발 개선 효과에 관한 연구. 한국인체미용예술학회지, 14: 249-262, 2013. 김경영, 배유경, 이은주, 김수미, 김은애, 최수기. (에센스) 화장품학. 메디시언, 파주, pp161-194, 2017. 김은철, 안소영, 홍은숙, 이광화, 김은기, 노경호. 천연물에 포함된 미백성분의 추출 및 미백효과. 공업화학, $16: 348-$ $353,2004$.

김은화. 천연 추출물을 이용한 미백화장품 개발 동향에 관한 연구. 아시안뷰티화장품학술지, 4: 195-203, 2006. 김형량, 정희종. 황칠나무 잎 및 종실의 화학적 특성. 한국농화학회지, 43: 63-66, 2000.

박수아, 박준, 박찬일, 지영종, 황윤찬, 김용현, 전소하, 이혜미, 하지훈, 김경진, et al. 황칠나무 잎 추출물의 세포 항산화

활성과 미백 활성 측정. 한국미생물·생명공학회지, 41: 407-415, 2013.

박수아, 하지훈, 박수남. 닥나무 추출물의 항산화 활성 및 성분 분석. 공업화학, 24: 177-183, 2013.

박윤점, 박용서, 장홍기, 김태춘, 허복구. 천연염료로서 복숭아나무 전정가지의 이용성. 한국자원식물학회지, 18: 71-77, 2005.

박준수, 김흥기. 미백 화장품 국내외 시장경쟁력 확보방안 연구. 국제지역연구, 21: 121-141, 2017.

배유경, 김주덕. 우리나라 여성들의 기능성 화장품에 대한 지식 및 이용행태 연구: 라이프 스타일을 중심으로. 대한화장품

학회지, 29: 251-270, 2003.

서민환, 이유미. 쉽게 찾는 우리 나무 1 산나무: 봄. 현문사, 서울, pp146-147, 2000.

손형우, 이숙희, 김민아, 박희준, 이상한. 도화 및 도화악 추출물의 미백활성 비교. 한국식품저장유통학회지, 19: 946-

$950,2012$. 
신혜진, 정향리, 황단비, 김동욱. 구찌뽕나무 뿌리 열수추출물로부터 미백 및 주름개선 화장품 소재의 개발. Korean Chemical Engineering Research, 52: 701-705, 2014.

안덕균. (원색)한국본초도감. 교학사, 서울, $\mathrm{pp} 1-98,1998$.

유익동, 김종평, 김원곤, 윤봉식, 유인자. 천연물 유래 항산화 기능성 화장품 신소재 개발. 대한화장품학회지, $31: 349-$ $357,2005$.

윤미연, 한은희, 한영숙. 질경이 seed 추출물을 항산화 활성 및 미백작용에 관한 연구. 한국인체미용예술학회지, 14 : 259-269, 2013.

이종구, 최지영, 오준석, 정희욱, 최은향, 이희상, 김정아, 장태수, 손종근, 이승호. 황백(黃柏)으로부터 멜라닌 생합성 억 제 물질의 분리. 생약학회지, 38: 387-393, 2007.

이진영, 안봉전. 도화(Prunus persica Flos) 분획물의 미백 및 주름개선 효과. 한국미생물·생명공학회지, 40: 364-370, 2010.

정병석, 조종수, 표병식, 황백. 황칠나무의 분포 및 황칠의 성분 분석에 관한 연구. KSBB Journal, 10: 393-400, 1995.

조영재. Phellodendron amurense의 미백물질을 이용한 화장품의 특성. Journal of Applied Biological Chemistry, 54: 108-113, 2011.

진경숙, 오유나, 박정애, 이지영, 진수정, 현숙경, 황혜진, 권현주, 김병우. 산초 추출물 및 분획물의 항산화, 미백 및 항염 증 활성. 한국미생물·생명공학회지, 40: 371-379, 2012.

최상원, 이유진, 하세비, 전영희, 이동희. 뽕나무(Morus alba L.) 부위별 생리활성 측정 및 기능성 물질 분석. 한국식품영 양과학회지, 44: 823-831, 2015.

타오샤오티엔, 이정희. 천연색소(코치닐색소, 락색소, 적무색소)를 이용한 립밤의 수분 및 만족도 평가. 한국인체미용예술 학회지, 19: 227-244, 2018.

하병조. 기능성화장품학. 신광출판사, 서울, $\mathrm{pp} 56-66,2016$.

한덕희, 박길순. 미백화장품의 구매실태 및 만족도 분석. 한국패션뷰티학회지, 4: 42-55, 2006.

한정선, 이동희. 솔잎 발효액의 항산화 활성 및 멜라닌 생성 억제 효과. 아시안뷰티화장품학술지, 10: 619-624, 2012.

한웅, 호위성, 이영미. 산초(Zanthoxylum schnifolium) 열매 분획물의 대장암세포(HT-29)에 대한 항암 효과. 생약학회 지, 42: 282-287, 2011. 


\section{中文摘要}

\section{天然美白原料的最新趋势}

鄭善熙

水原女子大学美容艺术科，京畿道水原市，韩国

本研究的目的是调查天然美白原料的最新研究趋势。在东方世界, 白晳的皮肤是衡量美的标准, 导致很多消费 者渴望拥有白晳的皮肤, 这是美白药妆品市场持续增长的关键因素。数百家公司, 包括AMORE PACIFIC和LG生 活健康, 争先恐后开发产品, 并通过市场调查和分析, 以系统和战略性的方式增加其范围。在化妆品行业中, 开发适合皮肤的高性能化学品非常重要。然而, 安全更是至关重要的, 因为这些产品将被应用到人体, 美白剂 和药物的副作用, 最近已有报道。因此, 有必要继续研究不仅要改善这些特性也提升了市场中期和长期增长。 本研究旨在综述目前天然皮肤美白产品的研究概况，并探讨其成分，特别以桃花李、黄柏、柘树、花椒、黃漆 木和楮木为考察对象。桃花、黄柏、黃漆木等植物表现出较高的黑色素合成的抑制率, 柘树和花椒科植物表现 出通过抑制酪氨酸酶抑制了二羟基苯丙氨酸（dihydroxyphenylalanine）的氧化作用。柘树通过消除活性氧 (reactive oxygen species，ROS）显示了抗氧化剂的作用。

关键词: 化妆品市场, 安全性, 美白剂, 天然, 成分 
